\title{
Effects of NPKS on Yield and Nutrition of BRRI dhan 49
}

\author{
Kamrunnahar ${ }^{1}$, S Ahmad ${ }^{1}$, M Iqbal $^{2}$, M N Islam² and A Islam²
}

\begin{abstract}
Nitrogen $(\mathrm{N})$, phosphorus $(\mathrm{P})$, potassium $(\mathrm{K})$ and sulphur $(\mathrm{S})$ strongly influence rice plant nutrition. Present experiment was conducted at the Bangladesh Rice Research Institute (BRRI) farm, Gazipur in a permanent layout in wet season of 2014. Objectives of the research were to study the effects of NPKS on grain yield, plant nutrition, requirement of NPKS to produce one ton grain and to estimate the indigenous nutrient supply of the soil. BRRI dhan 49 was tested with NPKS (complete), PKS (-N), NKS (-P), NPS (-K) and NPK (-S) fertilizer packages. The NPKS were applied @ 100-7-80-3 $\mathrm{kg} \mathrm{ha}^{-1}$. Omission of each nutrient from the complete treatments significantly reduced grain and straw yields of BRRI dhan 49 . The highest yield reduction was recorded because of $\mathrm{N}$ omission followed by $\mathrm{K}$. Nutrient concentration in grain and straw as well as nutrient uptakes were significantly affected by major plant nutrients. Nutrient uptake was directly related to the biomass production. About $87 \%$ of total $\mathrm{K}$ uptake remained in straw and thus a good K source for rice cultivation. Nitrogen, $\mathrm{P}, \mathrm{K}, \mathrm{S}$ and $\mathrm{Zn}$ required to produce one ton rice were 20.88, $5.04,18.77,2.08$ and $0.07 \mathrm{~kg}$, respectively. The indigenous $\mathrm{N}, \mathrm{P}, \mathrm{K}$ and $\mathrm{S}$ supply capacity of this soil was $37,13,41$ and $6 \mathrm{~kg} \mathrm{ha}^{-1}$, respectively.
\end{abstract}

Key words: Rice, nutrient uptake, indigenous nutrient, straw

\section{INTRODUCTION}

Rice production in Bangladesh needs to be increased to feed 215.4 million people in 2050 (Kabir et al., 2015). This can be done in two ways: expanding the rice growing area and increasing productivity, or both (Hasan et al., 2015). Crop productivity can be increased by supplying nutrients as per crop requirement or soil fertility management (Islam et al., 2016a) in different seasons. Among the seasons, wet season rice required less irrigation and fertilizer and farmers can be benefited by cultivating rice in this season.

Nitrogen, $\mathrm{P}, \mathrm{K}$ and $\mathrm{S}$ affect rice production and its physiological activity. Efficient use of $\mathrm{N}$ is an important complementary strategy for improving rice yield and reducing cost of production (Islam et al., 2016b). Phosphorus is intimately associated with all energy involved life processes and a vital constituent of every living cell. This element tends to be concentrated in the seed and stimulates early root formation and growth of the plant. Without adequate supply of $\mathrm{P}$ plant cannot reach its maximum yield. Since in many soils, much of the available $\mathrm{P}$ is derived through the mineralization of organic matter, the repeated addition of $\mathrm{P}$ fertilizer appears to be the only satisfactory way of supplying plant needs for this nutrient (Ali et al., 2004). Potassium is luxuriously absorbed by plants. Modern high-yielding rice varieties remove much higher amount of $\mathrm{K}$ than $\mathrm{P}$ or even $\mathrm{N}$ from the soil (Islam et al., 2015; Islam and Muttaleb, 2016; Islam et al., 2016c; Miah et al., 2008). It increases crop yields by accelerating photosynthesis, controlling stomata opening, efficient utilization of $\mathrm{N}$ and promoting the transport of assimilates. Sulphur deficiency is the cause of reduced plant height, reduced number of tillers, fewer and shorter panicles, reduced number of spikelets per panicle (Dobermann and Fairhurst, 2000). Problem of $S$ deficiency in soil can be aggravated with the use of excess $P$ fertilizer (Ali et al., 2004).

${ }^{1}$ Department of Botany, Jagannath University, Dhaka 1100, Bangladesh; ${ }^{2}$ Soil Science Division, BRRI, Gazipur 1701, Bangladesh. *Corresponding author's E-mail: aminbrri@gmail.com 
Among 30 agro ecological zones (AEZ), AEZs 28 (Madhupur Tract) is low in overall fertility status (FRG, 2012). Before fertilizer recommendation, it is necessary to determine the nutrient supply capacity of a soil, nutrient requirement and fertilizer recovery efficiency of a variety. Keeping these points in mind a field experiment was conducted in transplanted Aman (T. Aman) 2014 season (wet season) to study the effects of NPKS on grain yield, rice plant nutrition, requirement of NPKS to produce one ton grain and to estimate the indigenous nutrient supply of the soil.

\section{MATERIALS AND METHODS}

Soil, crop, experimental design and treatments An experiment was conducted in the research field of BRRI farm, Gazipur in a permanent layout first designed in Boro 1985. Initial soil of the experimental field was clay loam in texture having $\mathrm{pH}, 5.70,1.14 \%$ organic carbon, $0.08 \%$ total $\mathrm{N}, 9.80 \mathrm{ppm}$ available $\mathrm{P}, 70 \mathrm{mg}$ $\mathrm{kg}^{-1}$ exchangeable $\mathrm{K}, 9.00 \mathrm{ppm}$ available S and 3.30 ppm available Zn. In T. Aman 2014, BRRI dhan49 was tested with five fertilizer treatments: NPKS (complete), PKS (-N), NKS (-P), NPS (-K) and NPK (-S). NPKS @ 100-7-80$3 \mathrm{~kg} \mathrm{ha}^{-1}$. Dates of sowing and transplanting were 15 June 2014 and 21 July 2014, respectively. The experimental design was randomized complete block with three replications. Onethird of $\mathrm{N}$ as urea and the whole amount of $\mathrm{P}$ as triple super phosphate, $\mathrm{K}$ as muriate of potash and $\mathrm{S}$ as gypsum were applied at the final land preparation. The remaining twothird $\mathrm{N}$ was applied in two equal installments at 25-30 days after transplanting (DAT) and seven days before panicle initiation stage (PI stage). Two rice seedlings (36-day-old) were transplanted at $20 \times 20 \mathrm{~cm}$ spacing under irrigated condition. Appropriate cultural and management practices including plant protection measures were followed during growing season. All plots were surrounded by $30 \mathrm{~cm}$ soil levees to avoid contamination between plots.

\section{Data collection and analysis}

Grain yield. The crops were harvested at maturity from $2.5 \times 2 \mathrm{~m}$ area at $15 \mathrm{~cm}$ above ground level for grain yield calculation. Grain yields were recorded at $14 \%$ moisture content and calculated as follows:

$$
\text { Grain yield }\left(t h a^{-1}\right)=\frac{G W \times 10 \times(100-M)}{A \times 86}
$$

Where, GW = Grain weight in $\mathrm{kg}, \mathrm{M}=\%$ moisture of grain, $\mathrm{A}=$ Area of sample in $\mathrm{m}^{2}$

Straw yield. Straw yields were recorded from 16-hill sample harvested at the ground level from four corners and dry matter yield was calculated as:

$$
\text { Grain yield }\left(t h a^{-1}\right)=\frac{O D W \times F W T \times 10}{A \times F W S}
$$

Where, ODW = Oven dry weight of sub-sample in $\mathrm{g}, \mathrm{FWT}=$ Total fresh weight of harvested sample in g, FWS = Sub-sample fresh weight in $\mathrm{g}, \mathrm{A}=$ Area of sample in $\mathrm{m}^{2}$

\section{Plant nutrient composition}

Total nitrogen. Total $\mathrm{N}$ was determined following Micro Kjeldahl method (Steam distillation method). Total $\mathrm{N}$ uptake was determined by the following formulae:

Nitrogen uptake by grain $\left(\mathrm{kg} \mathrm{ha}^{-1}\right)=\frac{\% \mathrm{~N} \text { in grain } \times \text { grain yeild }\left(\mathrm{kg} \mathrm{ha}^{-1}\right)}{100}$
Nitrogen uptake by straw $\left(\mathrm{kg} \mathrm{ha}^{-1}\right)=\frac{\% \mathrm{~N} \text { in straw } \times \text { straw yeild }\left(\mathrm{kg} \mathrm{ha}^{-1}\right)}{100}$

Other nutrient uptake was determined similarly with respective nutrient concentration in grain and straw.

\section{Phosphorus, K, S and Zn}

Both straw and grain samples were digested using $\mathrm{HNO}_{3}-\mathrm{HClO}_{4}$ (5:2) di acid mixture. Phosphorus and $\mathrm{S}$ were determined colorimetrically with spectrophotometer (Model: V-630, Jasco). Potassium was determined by flame photometer (Model: 
410, Sherwood) and $\mathrm{Zn}$ by atomic absorption spectrophotometer (Model:170-30,HITACHI).

\section{Estimation of indigenous nutrient supply \\ Indigenous $\mathrm{N}$ supply $=$ Total $\mathrm{N}$ uptake $\left(\mathrm{kg} \mathrm{ha}^{-1}\right)$ in $\mathrm{N}$ omission plots (with full supply of $\mathrm{P}, \mathrm{K}$ and $\mathrm{S}$ ) \\ Indigenous $\mathrm{P}$ supply $=$ Total $\mathrm{P}$ uptake $\left(\mathrm{kg} \mathrm{ha}^{-1}\right)$ in $\mathrm{P}$ omission plots (with full dose of $\mathrm{N}, \mathrm{K}$ and $\mathrm{S}$ ) \\ Indigenous $\mathrm{K}$ supply $=$ Total $\mathrm{K}$ uptake $\left(\mathrm{kg} \mathrm{ha}^{-1}\right)$ in $\mathrm{K}$ omission plots (with full dose of N, P and S) \\ Indigenous $\mathrm{S}$ supply $=$ Total $\mathrm{S}$ uptake $\left(\mathrm{kg} \mathrm{ha}^{-1}\right)$ in $\mathrm{S}$ omission plots (with full dose of N, P and K)}

\section{Statistical analysis}

All data were analyzed statistically using CropStat software version 7.2.

\section{RESULTS AND DISCUSSION}

\section{Grain yield}

The highest grain yield of $4.90 \mathrm{t} \mathrm{ha}^{-1}$ was recorded with complete fertilizer (Table 1). Omission of $\mathrm{N}, \mathrm{P}, \mathrm{K}$ and $\mathrm{S}$ from complete fertilization significantly reduced grain yield by $1.94,1.25,1.34$ and $0.94 \mathrm{t} \mathrm{ha}^{-1}$ respectively. Omission of $\mathrm{K}$ and $\mathrm{N}$ gave significantly lower grain yield than $\mathrm{S}$ and $\mathrm{P}$ omission plots. This finding was similar with the observations of Miah et al. (2004).

\section{Straw yield}

Omission of $S$ produced the highest straw yield of $7.14 \mathrm{t} \mathrm{ha}^{-1}$ (Table 1) which was statistically identical with complete fertilization $\left(6.79 \mathrm{t} \mathrm{ha}^{-1}\right)$ and $\mathrm{P}$ omission plot $\left(6.47 \mathrm{tha}^{-1}\right)$. Omission of $\mathrm{N}$

Table 1. Effect of major nutrient elements on yield of $T$. Aman rice (var. BRRI dhan49), BRRI, Gazipur 2014.

\begin{tabular}{lcc}
\hline Treatment & Grain yield $\left(\mathrm{t} \mathrm{ha}^{-1}\right)$ & Straw yield $\left(\mathrm{t} \mathrm{ha}^{-1}\right)$ \\
\hline NPKS & 4.90 & 6.79 \\
$-\mathrm{N}$ & 2.96 & 4.90 \\
$-\mathrm{P}$ & 3.65 & 6.47 \\
$-\mathrm{K}$ & 3.56 & 6.05 \\
$-\mathrm{S}$ & 3.96 & 7.14 \\
LSD & 0.40 & 0.68 \\
CV $(\%)$ & 6.8 & 7.0 \\
\hline
\end{tabular}

produced the lowest straw yield followed by $\mathrm{K}$ omission. Omissions of $\mathrm{N}, \mathrm{P}, \mathrm{K}$ from complete fertilization reduced straw yield by $1.89,0.32$ and $0.74 \mathrm{t} \mathrm{ha}^{-1}$, respectively.

The higher grain yield with NPKS fertilizer might be due to the contribution of these nutrients to yield contributing characters of rice plant (Dubey et al., 2012). Potassium application helps to produce large amount of starch due to K-mediated carbohydrate metabolism (Islam et al., 2015). Sulphur application also helps to protein synthesis in rice grain and increases the grain weight, which is reflected in grain yield of rice (Singh and Singh, 2002).

\section{Nitrogen nutrition}

Different major plant nutrient elements significantly affected the $\mathrm{N}$ content, uptake and $\mathrm{N}$ required per ton rice production (Table 2). Grain N content varied from $0.68 \%$ in Nomission plot to $1.17 \%$ in $\mathrm{K}$ omission plot. Complete fertilization had the $1.16 \% \mathrm{~N}$ content in grains, which decreased to $0.68,0.85$ and $1.02 \%$ due to $\mathrm{N}, \mathrm{P}$ and $\mathrm{S}$ omissions, respectively. Straw $\mathrm{N}$ content varied from $0.35 \%$ in $\mathrm{N}$ omission plot to $0.70 \%$ in $\mathrm{P}$ omission plot. Complete fertilization had the straw $\mathrm{N}$ content of $0.67 \%$, which decreased to $0.35,0.52$ and $0.64 \%$ due to $\mathrm{N}, \mathrm{K}$ and $\mathrm{S}$ omissions, respectively. Increase of grain $\mathrm{N}$ under $\mathrm{K}$ omission might be due to the same ionic radius of $\mathrm{NH}_{4}^{+}$and $\mathrm{K}^{+}$ions. In the absence of $\mathrm{K}^{+}$ions plants absorb more $\mathrm{NH}_{4}^{+}$ ions. However, $\mathrm{P}$ omission slightly increased the straw $\mathrm{N}$ content of BRRI dhan49, which indicated the restriction of $\mathrm{N}$ translocation to the grain due to the lack of metabolic energy.

Grain N uptake varied from $20.13 \mathrm{~kg} \mathrm{ha}^{-1}$ in $\mathrm{N}$ omission plot to $56.84 \mathrm{~kg} \mathrm{ha}^{-1}$ in NPKS treated plot. Omissions of N, P, K and S from complete fertilization significantly reduced $\mathrm{N}$ uptake by $36.71,25.81,15.19$ and $16.45 \mathrm{~kg} \mathrm{ha}^{-1}$, respectively. Straw N uptake varied from $17.15 \mathrm{~kg} \mathrm{ha}^{-1}$ in N omission plot to $45.70 \mathrm{~kg} \mathrm{ha}^{-1}$ in S omission plot. Nitrogen uptake significantly decreased due to $\mathrm{N}$ and $\mathrm{K}$ omissions. Total $\mathrm{N}$ uptake varied from $37.28 \mathrm{~kg} \mathrm{ha}^{-1}$ in N omission plot to $102.33 \mathrm{~kg} \mathrm{ha}^{-1}$ in complete treatment. Omissions of N, P, K and $\mathrm{S}$ from complete fertilization significantly 
Table 2. Effect of major nutrient elements on N nutrition of T. Aman rice (var. BRRI dhan49), BRRI, Gazipur, 2014.

\begin{tabular}{|c|c|c|c|c|c|c|}
\hline \multirow[t]{2}{*}{ Treatment } & \multicolumn{2}{|c|}{$\mathrm{N}$ content $(\%)$} & \multicolumn{3}{|c|}{$\mathrm{N}$ uptake $\left(\mathrm{kg} \mathrm{ha}^{-1}\right)$} & \multirow{2}{*}{$\begin{array}{l}\text { N req } \\
\left(\mathrm{kg} \mathrm{t}^{-1}\right)\end{array}$} \\
\hline & Grain & Straw & Grain & Straw & Total & \\
\hline NPKS & 1.16 & 0.67 & 56.84 & 45.49 & 102.33 & 20.88 \\
\hline$-\mathrm{N}$ & 0.68 & 0.35 & 20.13 & 17.15 & 37.28 & 12.59 \\
\hline$-\mathrm{P}$ & 0.85 & 0.70 & 31.03 & 45.29 & 76.32 & 20.91 \\
\hline$-\mathrm{K}$ & 1.17 & 0.52 & 41.65 & 31.46 & 73.11 & 20.54 \\
\hline$-S$ & 1.02 & 0.64 & 40.39 & 45.70 & 86.09 & 21.74 \\
\hline $\operatorname{LSD}_{(0.05)}$ & 0.10 & 0.14 & 7.2 & 5.8 & 8.2 & 1.15 \\
\hline CV $(\%)$ & 5.7 & 6.5 & 7.6 & 5.5 & 4.5 & 9.2 \\
\hline
\end{tabular}

reduced total $\mathrm{N}$ uptake by $65.05,26.01,29.22$ and $16.24 \mathrm{~kg} \mathrm{ha}^{-1}$, respectively.

$\mathrm{N}$ required producing one ton rice grain varied from $12.59 \mathrm{~kg} \mathrm{t}^{-1}$ in $\mathrm{N}$ omission plot to $21.79 \mathrm{~kg} \mathrm{t}^{-1}$ in $\mathrm{S}$ omission plot. In complete fertilization, $\mathrm{N}$ required to produce one ton rice was $20.88 \mathrm{~kg}$ that decreased to $12.59,20.91$ and $20.54 \mathrm{~kg}$ due to $\mathrm{N}, \mathrm{P}$ and $\mathrm{K}$ omissions, respectively.

These results demonstrate the importance of $\mathrm{N}$ nutrition for lowland rice yield. Application of $\mathrm{K}$ in combination with $\mathrm{N}$ has synergistic influence in uptake, translocation and use of nutrients for assimilation in growth and development of final grain yield and its contributing attributes (Bukhsh et al., 2012).

\section{Phosphorus nutrition}

Grain P content varied from $0.22 \%$ in P omission plot to $0.34 \%$ in S omission plot (Table 3). Complete fertilization had the grain $\mathrm{P}$ content of $0.33 \%$, which decreased to $0.22 \%$, and $0.32 \%$ due to $\mathrm{P}$ and $\mathrm{K}$ omissions, respectively. Phosphorus omission significantly decreased grain P content of BRRI dhan49. Complete fertilization had $0.12 \%$ straw $\mathrm{P}$ content, which significantly decreased to $0.09 \%$, and $0.07 \%$ due to $\mathrm{N}$ and $\mathrm{P}$ omissions, respectively. Rice grown on a P deficient soil would not only give a poor grain yield but also would have low grain $\mathrm{P}$ content (BRRI, 2017; Saleque et al., 1998). Low P content in seeds would delay root growth and ultimately crop establishment especially under low soil P conditions.

Grain P uptake varied from $8.33 \mathrm{~kg} \mathrm{ha}^{-1}$ in $\mathrm{P}$ omission plot to $16.02 \mathrm{~kg} \mathrm{ha}^{-1}$ in complete fertilization. Omissions of $\mathrm{N}, \mathrm{P}, \mathrm{K}$ and $\mathrm{S}$ significantly reduced grain $\mathrm{P}$ uptake by 6.01 , $7.69,4.5$ and $2.36 \mathrm{~kg} \mathrm{ha}^{-1}$, respectively. Complete fertilization had straw P uptake of $8.37 \mathrm{~kg} \mathrm{ha}^{-1}$, which decreased to $4.18,4.26$ and $7.70 \mathrm{~kg} \mathrm{ha}^{-1}$ due to $\mathrm{N}, \mathrm{P}$ and $\mathrm{K}$ omissions, respectively. Total $\mathrm{P}$ uptake varied from $12.59 \mathrm{~kg} \mathrm{ha}^{-1}$ in $\mathrm{P}$ omissions plot to $24.39 \mathrm{~kg} \mathrm{ha}^{-1}$ in complete fertilized plot (Table 3). Omissions of N, P, K and $\mathrm{S}$ from complete fertilization significantly reduced total $\mathrm{P}$ uptake by 10.2, 11.8, 5.17 and $1.24 \mathrm{~kg} \mathrm{ha}^{-1}$, respectively.

$\mathrm{P}$ required for one ton rice grain yield varied from $3.36 \mathrm{~kg} \mathrm{t}^{-1}$ in P omission plot to 5.83 $\mathrm{kg} \mathrm{t}^{-1}$ in $\mathrm{S}$ omission plot (Table 3). In complete fertilization, $\mathrm{P}$ requirement was $5.04 \mathrm{~kg}$, which decreased to $4.75 \mathrm{~kg}$ and $3.36 \mathrm{~kg}$ due to $\mathrm{N}$ and $\mathrm{P}$ and omissions, respectively. Phosphorus omission plot showed significantly the lowest $P$ requirement.

\section{Potassium nutrition}

Different major plant nutrient elements significantly affected the straw K content, uptake and $\mathrm{K}$ requirement of BRRI dhan 49 (Table 4). However, grain $\mathrm{K}$ content was not affected by different major plant nutrients. Straw K content varied from $0.88 \%$ in $\mathrm{K}$ omission plot to $1.97 \%$ in $\mathrm{N}$ omission plot. Complete fertilization had the straw $\mathrm{K}$ content of $1.58 \%$, which decreased to $0.88 \%$ and 1.07 due to $\mathrm{K}$ and $\mathrm{S}$ omission, respectively. However, $\mathrm{N}$ omission slightly increased straw K content of BRRI dhan49. Potassium content was above critical limit except $\mathrm{K}$ omission plot. This result established 
Table 3. Effect of major nutrient elements on P nutrition of T. Aman rice (var. BRRI dhan49), BRRI, Gazipur, 2014.

\begin{tabular}{|c|c|c|c|c|c|c|}
\hline \multirow{2}{*}{ Treatment } & \multicolumn{2}{|c|}{ P content $(\%)$} & \multicolumn{3}{|c|}{ P uptake $\left(\mathrm{kg} \mathrm{ha}^{-1}\right)$} & \multirow{2}{*}{$\begin{array}{l}\text { P req. } \\
\left(\mathrm{kg} \mathrm{t}^{-1}\right)\end{array}$} \\
\hline & Grain & Straw & Grain & Straw & Total & \\
\hline NPKS & 0.33 & 0.12 & 16.02 & 8.37 & 24.39 & 5.04 \\
\hline$-\mathrm{N}$ & 0.33 & 0.09 & 10.01 & 4.18 & 14.19 & 4.75 \\
\hline$-\mathrm{P}$ & 0.22 & 0.07 & 8.33 & 4.26 & 12.59 & 3.36 \\
\hline$-K$ & 0.32 & 0.13 & 11.52 & 7.70 & 19.22 & 5.34 \\
\hline$-S$ & 0.34 & 0.13 & 13.66 & 9.48 & 23.15 & 5.83 \\
\hline $\operatorname{LSD}_{(0.05)}$ & 0.04 & 0.03 & 1.46 & 2.68 & 2.78 & 1.26 \\
\hline CV (\%) & 7.1 & 17.0 & 6.5 & 20.9 & 7.9 & 13.7 \\
\hline
\end{tabular}

Table 4. Effect of major nutrient elements on K nutrition of T. Aman rice (var. BRRI dhan49), BRRI, Gazipur, 2014.

\begin{tabular}{|c|c|c|c|c|c|c|}
\hline \multirow[t]{2}{*}{ Treatment } & \multicolumn{2}{|c|}{ K content $(\%)$} & \multicolumn{3}{|c|}{ K uptake (kg ha-1) } & \multirow{2}{*}{$\begin{array}{l}\text { K req. } \\
\left(\mathrm{kg} \mathrm{t}^{-1}\right)\end{array}$} \\
\hline & Grain & Straw & Grain & Straw & Total & \\
\hline NPKS & 0.30 & 1.58 & 14.33 & 76.86 & 91.19 & 18.77 \\
\hline$-\mathrm{N}$ & 0.29 & 1.97 & 8.73 & 59.06 & 67.79 & 22.66 \\
\hline$-\mathrm{P}$ & 0.25 & 1.67 & 9.32 & 62.58 & 71.90 & 19.21 \\
\hline$-K$ & 0.26 & 0.88 & 9.46 & 31.72 & 41.17 & 11.43 \\
\hline$-S$ & 0.30 & 1.07 & 12.03 & 42.87 & 54.89 & 13.66 \\
\hline $\operatorname{LSD}_{(0.05)}$ & NS & 0.20 & 2.03 & 5.93 & 7.42 & 2.18 \\
\hline CV $(\%)$ & 7.6 & 7.4 & 10.0 & 5.8 & 6.0 & 6.8 \\
\hline
\end{tabular}

the importance of $\mathrm{K}$ in rice plant nutrition. Increase in $\mathrm{K}$ concentration in rice plant with higher $\mathrm{K}$ rates might be due to higher uptake of $\mathrm{K}$ by plants. Similar results were reported by Hong and Huo (2004).

Grain K uptake varied from $8.73 \mathrm{~kg} \mathrm{ha}^{-1}$ in $\mathrm{N}$ omission plot to $14.33 \mathrm{~kg} \mathrm{ha}^{-1}$ in complete fertilization (Table 4). Omissions of N, P, K and $S$ from complete fertilization significantly reduced $\mathrm{K}$ uptake in grain by 5.6, 5.01, 4.87 and $2.3 \mathrm{~kg} \mathrm{ha}^{-1}$, respectively. Straw $\mathrm{K}$ uptake varied from $31.72 \mathrm{~kg} \mathrm{ha}^{-1}$ in $\mathrm{K}$ omission plot to $76.86 \mathrm{~kg} \mathrm{ha}^{-1}$ in complete fertilization. Omissions of $\mathrm{N}, \mathrm{P}, \mathrm{K}$ and $\mathrm{S}$ from complete fertilization significantly reduced $\mathrm{K}$ uptake by $17.8 \mathrm{~kg} \mathrm{ha}^{-1}, 14.28 \mathrm{~kg} \mathrm{ha}^{-1}, 45.14$ and 33.99 $\mathrm{kg} \mathrm{ha}^{-1}$, respectively. Total $\mathrm{K}$ uptake varied from $41.17 \mathrm{~kg} \mathrm{ha}^{-1}$ in $\mathrm{K}$ omission plot to 91.19 $\mathrm{kg} \mathrm{ha}{ }^{-1}$ in complete fertilization. Omissions of $\mathrm{N}, \mathrm{P}, \mathrm{K}$ and $\mathrm{S}$ from complete fertilization significantly reduced total $\mathrm{K}$ uptake by 23.4 , $19.29,50.02$ and $36.3 \mathrm{~kg} \mathrm{ha}{ }^{-1}$, respectively. Potassium omission significantly decreased total K uptake of BRRI dhan49. More K uptake might be due to satisfactory availability of applied K. Bahmaniar and Ranjbar (2007) elucidated that $\mathrm{K}$ uptake in shoot and grain was significantly affected by cultivar and $\mathrm{K}$ treatment interaction.

$\mathrm{K}$ required producing one ton rice grain varied from $11.43 \mathrm{~kg} \mathrm{t}^{-1}$ in $\mathrm{K}$ omission plot to $22.66 \mathrm{~kg} \mathrm{t}^{-1}$ in $\mathrm{N}$ omission plot. In complete fertilization $\mathrm{K}$ required to produce one ton rice was $18.77 \mathrm{~kg}$, which decreased to 19.21 , 11.43 and $13.66 \mathrm{~kg}$ due to $\mathrm{P}, \mathrm{K}$ and $\mathrm{S}$ omission, respectively. The $\mathrm{K}$ omission plot showed significantly the lowest $\mathrm{K}$ requirement to produce one ton of rice. Nitrogen omission showed the highest $\mathrm{K}$ requirement to produce one ton of rice in BRRI dhan 49.

\section{Potassium distribution}

Distribution of $\mathrm{K}$ in rice grain varied from $12.96 \%$ in $\mathrm{P}$ omission plot to $23.00 \%$ in $\mathrm{K}$ omission plot (Table 5). Potassium omission slightly increased $\mathrm{K}$ percentage, but $\mathrm{P}$ omission 
Table 5. Effect of major nutrient elements on $\mathrm{K}$ distribution and N:K ratio in straw of T. Aman rice (var. BRRI dhan49), BRRI, Gazipur, 2014.

\begin{tabular}{lccc}
\hline \multirow{2}{*}{ Treatment } & \multicolumn{2}{c}{ K distribution $(\%)$} & N:K ratio in straw \\
\cline { 2 - 3 } & Grain & Straw & \\
\hline NPKS & 15.70 & 84.30 & 0.42 \\
$-\mathrm{N}$ & 22.88 & 87.12 & 0.18 \\
$-\mathrm{P}$ & 12.96 & 87.04 & 0.42 \\
$-\mathrm{K}$ & 23.00 & 77.00 & 0.59 \\
$-\mathrm{S}$ & 21.89 & 78.11 & 0.60 \\
LSD & 2.48 & 2.48 & 0.20 \\
CV (\%) & 1.6 & 7.6 & 12.0 \\
\hline
\end{tabular}

slightly decreased its percentage in grain of T. Aman rice (BRRI dhan49). Percentage of $\mathrm{K}$ in straw varied from $77.0 \%$ in $\mathrm{K}$ omission plot to $87.12 \%$ in $\mathrm{N}$ omission plot. Complete fertilization had $84.30 \%$ straw K, which decreased to $77.0 \%$, and $78.11 \%$ due to $\mathrm{K}$ and $\mathrm{S}$ omission, respectively. However $\mathrm{N}$ and $\mathrm{P}$ omission significantly increased the percentage of $\mathrm{K}$ in straw of BRRI dhan 49.

The higher percentage of $\mathrm{K}$ in rice straw compared to grain has been widely reported (Fageria et al., 2010; Islam et al., 2016c). Fageria et al. (2010) reported 5.5 times higher straw $\mathrm{K}$ uptake than rice grain $\mathrm{K}$ uptake. Hence, incorporation of rice straw in the soil after harvest of this crop may contribute significantly to maintaining $\mathrm{K}$ status of rice soil.

\section{$\mathrm{N}: \mathrm{K}$ ratio in straw}

The $\mathrm{N}: \mathrm{K}$ ratio in straw varied from 0.18 in $\mathrm{N}$ omission plot to 0.60 in $S$ omission plot (Table 5). Over all $\mathrm{N}: \mathrm{K}$ ratio of BRRI dhan 49 seems to low for proper growth and development. Ravichandran and Sriramachandrasekharan (2011) reported that the $\mathrm{N}: \mathrm{K}$ ratio in rice straw should be between 1.0 and 0.71 (1:1 to $1: 1.4)$ for optimum growth of the plant. In this study the $\mathrm{N}: \mathrm{K}$ ratio was lower than the reported range indicating the insufficient dose of $\mathrm{N}$ applied. So, it is very much essential to maintain proper $\mathrm{N}: \mathrm{K}$ ratio in rice straw for optimum rice plant growth. Nitrogen and potassium should be applied in suitable ratio for optimum yield.

\section{Sulphur nutrition}

Different major nutrient elements significantly affected straw $S$ content and uptake by BRRI dhan49. However, grain $S$ content was not affected by different major plant nutrients (Table 6). Grain $S$ uptake varied from $1.80 \mathrm{~kg}$ ha $^{-1}$ in N omission plot to $3.42 \mathrm{~kg} \mathrm{ha}^{-1}$ in complete fertilized plot. Complete fertilization had the highest grain $S$ uptake of $3.42 \mathrm{~kg} \mathrm{ha}^{-1}$. Omissions of $\mathrm{N}, \mathrm{P}, \mathrm{K}$ and $\mathrm{S}$ from complete fertilization significantly reduced $S$ uptake by $1.62,0.43$, 0.89 and $1.29 \mathrm{~kg} \mathrm{ha}^{-1}$, respectively. Straw $\mathrm{S}$ uptake varied from $3.69 \mathrm{~kg} \mathrm{ha}^{-1}$ in $\mathrm{N}$ omission plot to $6.70 \mathrm{~kg} \mathrm{ha}^{-1}$ in complete fertilization plot. Complete fertilization had the highest straw $\mathrm{S}$ uptake of $6.70 \mathrm{~kg} \mathrm{ha}{ }^{-1}$. Omission of N, P, K and $\mathrm{S}$ from complete treatment significantly reduced $S$ uptake by 3.01, 1.63, 1.34 and $2.5 \mathrm{~kg}$ $\mathrm{ha}^{-1}$, respectively. These results corroborates well with the findings of Islam et al. (1997). They reported that application of $S$ significantly increased $S$ uptake in rice. Total $S$ uptake varied from $5.49 \mathrm{~kg}^{-1}$ in $\mathrm{N}$ omission plot to $10.12 \mathrm{~kg}$ $\mathrm{ha}^{-1}$ in complete fertilization. Omissions of $\mathrm{N}, \mathrm{P}$, $\mathrm{K}$ and $\mathrm{S}$ from complete treatment significantly reduced total $S$ uptake by $4.63,2.06,2.22$ and $3.78 \mathrm{~kg} \mathrm{ha}^{-1}$, respectively. Sulphur required to produce one ton rice grain was not affected by different major plant nutrients.

\section{Zinc nutrition}

Different major plant nutrient elements significantly affected $\mathrm{Zn}$ content in straw and Zn uptake (Table 7). However, Zn content in grain and $\mathrm{Zn}$ requirement was not affected by different major plant nutrients. Straw Zn content varied from $24.18 \mathrm{ppm}$ in $\mathrm{N}$ omission plot to $36.57 \mathrm{ppm}$ in NPKS treated plot. Omission of $\mathrm{N}, \mathrm{P}, \mathrm{K}$ and $\mathrm{S}$ had statistically similar straw $\mathrm{Zn}$ content.

Grain Zn uptake varied from $0.06 \mathrm{~kg} \mathrm{ha}^{-1}$ in $\mathrm{N}$ omission plot to $0.10 \mathrm{~kg} \mathrm{ha}^{-1}$ in complete fertilization. Complete fertilization had the highest grain $\mathrm{Zn}$ uptake, which decreased to $0.06,0.08,0.08$ and $0.08 \mathrm{~kg} \mathrm{ha}^{-1}$ due to $\mathrm{N}, \mathrm{P}, \mathrm{K}$ and $S$ omission, respectively. Omission of $\mathrm{P}$, $\mathrm{K}$ and $\mathrm{S}$ had statistically similar $\mathrm{Zn}$ uptake. Straw Zn uptake varied from $0.11 \mathrm{~kg} \mathrm{ha}^{-1}$ in 
Table 6. Effect of major nutrient elements on S nutrition of T. Aman rice (var. BRRI dhan49), BRRI, Gazipur, 2014.

\begin{tabular}{|c|c|c|c|c|c|c|}
\hline \multirow[t]{2}{*}{ Treatment } & \multicolumn{2}{|c|}{ S content $(\%)$} & \multicolumn{3}{|c|}{ S uptake $\left(\mathrm{kg} \mathrm{ha}^{-1}\right)$} & \multirow{2}{*}{$\begin{array}{l}\text { S req. } \\
\left(\mathrm{kg} \mathrm{t}^{-1)}\right.\end{array}$} \\
\hline & Grain & Straw & Grain & Straw & Total & \\
\hline NPKS & 0.07 & 0.10 & 3.42 & 6.70 & 10.12 & 2.08 \\
\hline$-\mathrm{N}$ & 0.06 & 0.08 & 1.80 & 3.69 & 5.49 & 1.83 \\
\hline$-\mathrm{P}$ & 0.08 & 0.08 & 2.99 & 5.07 & 8.06 & 2.16 \\
\hline$-K$ & 0.07 & 0.09 & 2.53 & 5.36 & 7.90 & 2.19 \\
\hline$-S$ & 0.05 & 0.06 & 2.13 & 4.20 & 6.34 & 1.58 \\
\hline $\mathrm{LSD}_{(0.05)}$ & NS & 0.02 & 1.01 & 1.32 & 1.97 & NS \\
\hline CV (\%) & 18.2 & 12.1 & 20.9 & 14.0 & 13.8 & 14.9 \\
\hline
\end{tabular}

Table 7. Effect of major nutrient elements on zinc (Zn) nutrition of T. Aman rice (var. BRRI dhan49), BRRI, Gazipur, 2014.

\begin{tabular}{|c|c|c|c|c|c|c|}
\hline \multirow[t]{2}{*}{ Treatment } & \multicolumn{2}{|c|}{ Zn content $(\mathrm{ppm})$} & \multicolumn{3}{|c|}{ Zn uptake $\left(\mathrm{kg} \mathrm{ha}^{-1}\right)$} & \multirow{2}{*}{$\begin{array}{l}\text { Zn req. } \\
\left(\mathrm{kg} \mathrm{t}^{-1}\right)\end{array}$} \\
\hline & Grain & Straw & Grain & Straw & Total & \\
\hline NPKS & 21.02 & 36.57 & 0.10 & 0.25 & 0.35 & 0.07 \\
\hline$-\mathrm{N}$ & 19.10 & 24.18 & 0.06 & 0.11 & 0.17 & 0.06 \\
\hline$-\mathrm{P}$ & 20.15 & 29.18 & 0.08 & 0.19 & 0.26 & 0.07 \\
\hline$-\mathrm{K}$ & 21.90 & 28.16 & 0.08 & 0.17 & 0.25 & 0.07 \\
\hline$-S$ & 21.10 & 27.27 & 0.08 & 0.19 & 0.28 & 0.07 \\
\hline $\operatorname{LSD}_{(0.05)}$ & NS & 7.07 & 0.02 & 0.05 & 0.05 & NS \\
\hline CV (\%) & 10.5 & 12.9 & 13.5 & 13.7 & 10.0 & 11.3 \\
\hline
\end{tabular}

$\mathrm{N}$ omission plot to $0.25 \mathrm{~kg} \mathrm{ha}^{-1}$ in complete fertilized plot. Omissions of N, P, K and $S$ from complete fertilization significantly reduced $Z n$ uptake by $0.14,0.06,0.08$ and 0.06 $\mathrm{kg} \mathrm{ha}^{-1}$, respectively. Total $\mathrm{Zn}$ uptake varied from $0.17 \mathrm{~kg} \mathrm{ha}^{-1}$ in $\mathrm{N}$ omission plot to 0.35 $\mathrm{kg} \mathrm{ha}^{-1}$ in complete fertilized plot. Complete fertilization had the highest total $\mathrm{Zn}$ uptake of $0.35 \mathrm{~kg} \mathrm{ha}^{-1}$. Omission of N, P, K and S from complete fertilization significantly reduced total $\mathrm{Zn}$ uptake by $0.18,0.09,0.1$ and $0.07 \mathrm{~kg}$ ha $^{-1}$, respectively.

\section{Nutrient supply capacity and recovery efficiency of soil}

Calculated indigenous nutrient supply capacities of soil were NPKS @ 37.28, 12.59, 41.17 and $6.34 \mathrm{~kg} \mathrm{ha}^{-1}$ to the T. Aman rice crop.

Nitrogen recovery varied from 35.83 to $65.05 \%$. The highest $\mathrm{N}$ recovery was observed in complete fertilization and the lowest was in $\mathrm{K}$ omission plot (Table 8). Phosphorus recovery varied from 22.86 to $168.57 \%$. Like
$\mathrm{N}, \mathrm{P}$ recovery also the highest in complete fertilization. The lowest $\mathrm{P}$ recovery was in $\mathrm{N}$ omission treatment. Recovery of applied K ranged from 17.15 to $62.53 \%$ being the highest in complete fertilization. Sulphur recovery ranged from -28.33 to $126.00 \%$ being the highest again in complete fertilization.

Nitrogen use efficiency in wetland rice is only $30-50 \%$. However, Fageria and Baligar (2005) found nitrogen recovery efficiency for lowland rice less than $50 \%$. In the present

Table 8. Recovery efficiency of applied nutrients for $T$. Aman rice (var. BRRI dhan49) in Grey Terrace soil, BRRI, Gazipur 2014.

\begin{tabular}{lcccc}
\hline \multirow{2}{*}{ Treatment } & \multicolumn{4}{c}{ Recovery efficiency (\%) } \\
\cline { 2 - 5 } & $\mathrm{N}$ & $\mathrm{P}$ & $\mathrm{K}$ & $\mathrm{S}$ \\
\hline NPKS & 65.05 & 168.57 & 62.53 & 126.00 \\
$-\mathrm{N}$ & - & 22.86 & 33.28 & -28.33 \\
$-\mathrm{P}$ & 39.04 & - & 38.41 & 57.33 \\
$-\mathrm{K}$ & 35.83 & 94.71 & - & 52.00 \\
$-\mathrm{S}$ & 48.81 & 150.86 & 17.15 & - \\
\hline
\end{tabular}


study, higher $\mathrm{N}$ recovery is due to lower rate of $\mathrm{N}$ application. The recovery efficiency of $\mathrm{P}$ throughout the world is not more than $20 \%$ of applied P (Qureshi et al., 2012). In this study very high recovery of $\mathrm{P}$ was recorded. This might be due to lower $\mathrm{P}$ dose and higher availability of soil native $\mathrm{P}$ and residual effect of $\mathrm{P}$ applied in the previous crop. Yulin Liao et al. (2010) reported that the average value of $\mathrm{K}$ recovery efficiency for the three $\mathrm{K}$ fertilizer treatments $\left(112.5,150\right.$ and $187.5 \mathrm{~kg} \mathrm{~K}_{2} \mathrm{O} \mathrm{ha}^{-1}$ ) in the reddish-yellow paddy soil was $35.0 \%$ for early rice and $51.8 \%$ for late rice; while the comparative figures for the purple calcareous clayey soil were $27.1 \%$ for early rice and $42.6 \%$ for late rice. While in this study $62.53 \% \mathrm{~K}$ recovery was recorded with NPKS fertilization.

\section{CONCLUSION}

Major plant nutrients significantly affected the yield, nutrient concentration and uptake of $\mathrm{T}$. Aman rice (BRRI dhan49). Major portion of absorbed $\mathrm{K}$ remain in rice straw. So, rice straw should be recycled in the field for K source. The indigenous $\mathrm{N}, \mathrm{P}, \mathrm{K}$ and $\mathrm{S}$ supply capacity of this soil was 37, 13, 41 and $6 \mathrm{~kg} \mathrm{ha}^{-1}$, respectively. A good recovery of applied nutrients was also observed in this soil.

\section{REFERENCES}

Ali, M M, M S Mian and A Islam. 2004. Interaction effects of sulphur and phosphorus on wetland rice. Asian J. Plant Sci. 3 (5): 597-601.

Bahmaniar, M A and G A Ranjbar 2007. Effects of nitrogen and potassium fertilizers on rice (Oryza sativa L.) genotypes processing characteristics. Pak. J. Biol. Sci. 10(11): 829-1834.

BRRI (Bangladesh Rice Research Institute). 2017. In: Annual Internal Research Review Workshop 2015-16. VIII. Soil Science. 26 January-2 February 2017. Bangladesh Rice Res. Inst. Gazipur, Bangladesh.

Bukhsh, M A, A H A Ahmad, R Iqbal, J Maqbool, M M Ali, M Ishaque and S Hussain. 2012. Nutritional and physiological significance of potassium application in maize hybrid crop production. Pak J. Nutr. 11: 187-202.
Dobermann, A and T H Fairhurst. 2000. Rice: Nutrient disorders and nutrient management. Handbook Series. Potash and Phosphate Institute (PPI), Potash and Phosphate Institute of Canada (PPIC) and International Rice Research Institute (IRRI). $191 \mathrm{p}$.

Dubey, V, A K Patel, A Shukla, S Shukla and S Singh. 2012. Impact of continuous use of chemical fertilizer. Indian J. Fertilizer. 3: 13-16.

Fageria, N K and V C Baligar. 2005. Enhancing nitrogen use efficiency in crop plants. Adv. Agron. 88: 97-185.

Fageria, N K, A B Dos Santos, A Moreira and M F de Moraes. 2010. Potassium soil test calibration for lowland rice on an inceptisol. Commun. Soil Sci. Plant Anal. 41: 2595-2601.

FRG. 2012. Fertilizer recommendation guide. Farmgate, Dhaka 1215: Bangladesh Agricultural Research Council (BARC), p. 274.

Hasan, M J, M H Rahman, A Akter, M U Kulsum and A Islam. 2015. Assessment of appropriate doses of GA3 and row ratio for better seed yield of a promising hybrid rice variety. Bangladesh Rice J. 19 (1): 49-53.

Hong, H and W G Huo. 2004. Nutrient uptake and use efficiency of irrigated rice in response to potassium application. Pedosphere 14: 125-130.

Islam, M R, T M Riasat and M Jahiruddin. 1997. Direct and residual effects of $S, \mathrm{Zn}$ and $\mathrm{B}$ on yield, nutrient uptake in a rice-mustard cropping system. J. Indian Soc. Soil Sci. 45(10): 126-129.

Islam, A, J C Biswas, A J M S Karim, M Salmapervin and M A Saleque. 2015. Effects of potassium fertilization on growth and yield of wetland rice in grey terrace soils of Bangladesh. Res. Crop Ecophysiol. J. 10 (2): 64-82.

Islam, A and A Muttaleb. 2016. Effect of potassium fertilization on yield and potassium nutrition of Boro rice in a wetland ecosystem of Bangladesh. Archives of Agron. Soil Sci. 62 (11): 1530-1540. [cited 2016 March 19], available from: http:/ / dx.doi.org/1 0.1080/03650340.2016.1157259

Islam, M N, M I U Sarkar, M H Ali, A Islam and P K Saha. 2016a. IPNS based fertilizer management for rice in coastal zone of Bangladesh. Bangladesh J. Agril. Res. 41 (4): 667-673.

Islam, M N, A Islam and J C Biswas. 2016b. Genotypic variations in modern rice and nitrogen use efficiency. Int. J. Agril. Papers 1 (2): 27-35.

Islam, A, P K Saha, J C Biswas and M A Saleque. 2016c. Potassium fertilization in intensive wetland rice system: yield, potassium use efficiency and soil potassium status. Int. J. Agril. Papers 1 (2): 7-21. 
Kabir, M S, M U Salam, A Chowdhury, N M F Rahman, K M Iftekharuddaula, M S Rahman, M H Rashid, S S Dipti, A Islam, M A Latif, A K M S Islam, M M Hossain, B Nessa, T H Ansari, M A Ali and J K Biswas. 2015. Rice vision for Bangladesh: 2050 and beyond. Bangladesh Rice J. 19(2): 1-18.

Miah, M A M, P K Saha, A Islam, M N Hasan and V Nosov. 2008. Potassium fertilization in rice-rice and ricewheat cropping system in Bangladesh. Bangladesh J. Agric. and Environ. 4: 51-67, Special Issue 2008.

Miah, M N H, S Talukder, M A R Sankar and T H Ansari. 2004. Effect of number of seedling per hill and urea super granules on growth and yield of rice cv. BINA dhan4. J. Biol. Sci. 4(2): 122-129.

Qureshi, M A, Ahmad Z A, N Akhtar and A Iqbal. 2012. Role of phosphate solubilizing bacteria (PSB) in enhancing P-availability and promoting cotton growth. J. Anim. Plant Sci. 22: 204-210.
Ravichandran, M and M V Sriramachandrasekharan. 2011. Optimizing timing of potassium application in productivity enhancement of crops. Karnataka J. Agric. Sci. 24: 75-80.

Saleque, M A, M J Abedin, G M Panaullah and N I Bhuiyan. 1998. Yield and phosphorus efficiency of some lowland rice varieties at different levels of soilavailable phosphorus, Commun. in Soil Sci. and Plant Anal. 29 (19-20): 2905-2916.

Singh, C S and U N Singh. 2002. Effect of nitrogen and sulphur nutrition on growth and yield of rice (Oryza sativa L.) cultivars. Res. on Crops. 3(3): 643-646.

Yulin Liao, Shengxian Zheng, Jun Nie, Yanhong Lu and Jian X. 2010. Potassium efficiency and potassium balance of the rice-rice cropping system under two different agro-ecosystems. Electronic international fertilizer correspondence (e-ifc) No. 24, September 2010. pp:15-20. 
